\title{
Rapid metabolic adaptation in European sea bass (Dicentrarchus labrax) juveniles fed different carbohydrate sources after heat shock stress
}

\author{
P. Enes ${ }^{a, b}$, S. Panserat ${ }^{c}$, S. Kaushik ${ }^{c}$ and A. Oliva-Teles ${ }^{a, b, *}$
}

\author{
a Departamento de Zoologia e Antropologia, Faculdade de Ciências da Universidade do Porto, 4099-002 Porto, \\ Portugal \\ ${ }^{\mathrm{b}}$ CIIMAR-Centro Interdisciplinar de Investigação Marinha e Ambiental, 4050-123 Porto, Portugal \\ c UMR Inra-Ifremer-Bordeaux1 NuAGe (Nutrition Aquaculture et Genomique), 64310 St-Pee-sur-Nivelle, France
}

*: Corresponding author : A. Oliva-Teles, Tel.: +351 22340 1507; fax: +351 22340 1511, email address : aoteles@fc.up.pt

\begin{abstract}
:
A study was conducted to evaluate the effect of two dietary carbohydrate sources (waxy maize starch and glucose) on the metabolic adaptation of sea bass juveniles (initial weight: $24 \mathrm{~g}$ ) to a heat shock treatment (temperature rise from $18{ }^{\circ} \mathrm{C}$ to $25^{\circ} \mathrm{C}$ within $24 \mathrm{~h}$ ). Two isonitrogenous and isolipidic diets were formulated to contain $20 \%$ waxy maize starch (WS diet) or $20 \%$ glucose (GLU diet). Triplicate groups of fish were fed to near satiation for 4 weeks at both temperatures $\left(18{ }^{\circ} \mathrm{C}\right.$ and $\left.25^{\circ} \mathrm{C}\right)$. Then, fish previously maintained at $18{ }^{\circ} \mathrm{C}$ were submitted to a heat shock $\left(18{ }^{\circ} \mathrm{C}\right.$ to $\left.25^{\circ} \mathrm{C}\right)$ and continued to be fed with the same diets during 1 more week. The higher water temperature significantly improved growth performance, feed efficiency, as well as protein efficiency ratio, independently of diet. At $25^{\circ} \mathrm{C}$, but not at $18{ }^{\circ} \mathrm{C}$, growth of fish fed the WS diet was higher than that of fish fed the GLU diet. Plasma glucose levels were higher in sea bass fed the GLU diet and not influenced by water temperature. Fish fed a glucose diet or reared at high temperatures $\left(25^{\circ} \mathrm{C}\right)$ showed enhanced liver glycolytic, lipogenic and gluconeogenic capacities compared to fish fed a starch diet or reared at low temperatures $\left(18{ }^{\circ} \mathrm{C}\right)$. For the majority of the enzymes studied, 1 week seemed to be enough time for metabolic adaptation in sea bass submitted to an acute heat shock.

Irrespective of carbohydrate source, HSP70 gene expression was similar in both cold water $\left(18{ }^{\circ} \mathrm{C}\right)$ and warm water $\left(25^{\circ} \mathrm{C}\right)$ acclimated sea bass. A weak down regulation was observed after heat shock only in fish fed the GLU diet. This suggests that HSP70 gene expression is not affected by the rearing temperature per se.
\end{abstract}

Keywords: Biomarker; Carbohydrate utilization; European sea bass; Gluconeogenic enzymes; Glucose; Glycolytic enzymes; HSP70; Lipogenic enzymes; Temperature; Waxy maize starch 


\section{1. Introduction}

2

5 However, protein is one of the most expensive components of diets and excess protein $9 \quad$ Kaushik and Médale, 1994).

Carnivorous fish require high-protein diets to obtain amino acids for use in protein synthesis, glucose synthesis and for energy purposes (Sánchez-Muros et al., 1998). increases $\mathrm{N}$ excretion. Therefore, both from an economical and an environmental point of view, it is advisable to spare protein for plastic purposes by increasing the utilization of conventional energy sources like lipids or carbohydrates (Cho and Kaushik, 1990;

Although carbohydrates are the cheapest energy source, most teleosts do not tolerate high dietary carbohydrate levels, and maximum dietary inclusion level depends on fish species. It is generally assumed that optimal dietary digestible carbohydrate level is less than $20 \%$ for carnivorous fish, whereas it is much higher (30-40\%) for omnivorous fish (Wilson, 1994). For European sea bass, there is evidence that a dietary incorporation of 20-25\% of digestible carbohydrate does not affect growth or feed efficiency (Gouveia et al., 1995; Lanari et al., 1999; Peres and Oliva-Teles, 2002).

The complexity of carbohydrate molecule also affects carbohydrate utilization. For example, starch has been demonstrated to be used more efficiently than glucose in both marine and fresh water species: carp, red sea bream (Furuichi and Yone, 1982), yellowtail (Furuichi et al., 1986), tilapia (Anderson et al., 1984; Shiau and Peng, 1993), white sturgeon (Deng et al., 2005). On the contrary, juvenile grass carp (Tian and Liu, 2004) and rainbow trout (Bergot, 1979a; Hung and Storebakken, 1994) appears to utilise glucose better than starch. However, also in rainbow trout (Pieper and Pfeffer, 
1 1980a; 1980b) and in grouper (Shiau and Lin, 2001) starch seems to be used as

2 efficiently as glucose.

3

Various factors affect the digestible energy provided by complex carbohydrates

5 in fish diets (Bergot, 1993). One of these factors is the technological treatment of starch.

6 Contrary to normal maize, which contains 25-28\% amylose, waxy maize only contains

7 1\% (Pfeffer et al., 1991; Bergot, 1993). Bergot (1993) measured the digestibility of

8 starch of different botanical origins by rainbow trout and found that digestibility of

9 waxy maize starch was significantly higher than that of amylomaize or normal maize.

10 Pfeffer et al. (1991) also found that rainbow trout performed better with waxy than

11 normal maize starch.

For European sea bass, data on the utilization of different carbohydrate sources

14 is still limited. Alliot et al. (1979) observed a protein sparing effect of glucose, although

15 growth depression occured at high dietary inclusion levels. Despite differences in

16 carbohydrate digestibility, Alliot et al. (1984) observed similar growth performance of

17 sea bass fed diets including either maltose or starch. Although the effect of starch

18 gelatinization on growth performance is somewhat discordant (Gouveia et al., 1995;

19 Dias et al., 1998; Peres and Oliva-Teles, 2002) it is well established that gelatinization

20 of starch improves carbohydrate digestibility (Dias et al., 1998; Peres and Oliva-Teles,

21 2002). Also in sea bass, digestibility of waxy maize starch was higher than that of

22 normal maize starch (Enes et al., in press). 
Water temperature is an important environmental factor affecting physiological

2 and biochemical functions in fish (Jobling, 1994), as well as the activities of several

3 hepatic enzymes (Shikata et al., 1995). In sea bass, temperature plays an important role

4 in governing growth via its effects on feeding rate and metabolism (Person-Le Ruyet et

5 al., 2004). The increase of water temperature from $18^{\circ} \mathrm{C}$ to $25^{\circ} \mathrm{C}$ improved growth and

6 feed efficiency of sea bass juveniles (Peres and Oliva-Teles, 1999; Person-Le Ruyet et

7 al., 2004). Although protein utilization seems to be affected by temperature (Peres and

8 Oliva-Teles, 1999) the optimum dietary protein inclusion level is independent of water

9 temperature (Alliot et al., 1974; Hidalgo and Alliot, 1988; Peres and Oliva-Teles, 1999).

11 Heat shock proteins (HSP) are a wide family of conserved proteins, classified 12 according to their molecular weight, present in all organisms including fish (Basu et al., 13 2002). HSP70 is known to assist the folding of nascent polypeptide chains, act as a 14 molecular chaperone, and mediate the repair and degradation of altered or denatured 15 proteins (Basu et al., 2002). Thus, HSP70 has been most widely used as a biomarker of 16 stress. In fish, like in mammals, HSP70 is induced by heat and chemical shocks

17 (Gornati et al., 2004). In sea bass, HSP70 was also shown to be inducible by rearing 18 density (Gornati et al., 2004).

According to our knowledge, there are no previous studies with sea bass 21 comparing starch and glucose utilization at different water temperatures. Thus, the 22 purpose of the present study was to evaluate the effect of two water temperatures $\left(18^{\circ} \mathrm{C}\right.$ 23 and $25^{\circ} \mathrm{C}$ ) and two carbohydrate sources (waxy maize starch and glucose) on growth 24 performance and activities of hepatic enzyme related to glycolysis, gluconeogenesis and 25 lipogenesis in European sea bass juveniles. 


\section{2. Material and methods}

2

3 2.1. Diets

4

Two isonitrogenous (48\% crude protein) and isolipidic (18\% crude lipids) diets were formulated to contain $20 \%$ of either waxy maize starch (diet WS) or glucose (diet GLU). Waxy maize starch (99\% amylopectin, 1\% amylose) was purchased from Cerestar (Mechelen, Belgium) and D(+)-Glucose from MERCK. All dietary ingredients were finely ground, mixed thoroughly and dry pelleted in a laboratory pellet mill (CPM) through a $3 \mathrm{~mm}$ die. Ingredients and proximate composition of the experimental diets are presented in Table 1.

\subsection{Fish rearing}

Fish used in this study were European sea bass (Dicentrarchus labrax) juveniles obtained from a commercial hatchery. The first part of the trial lasted 4 weeks and was performed in two independent partial water recirculation systems, thermoregulated to $18.3 \pm 0.5^{\circ} \mathrm{C}$ and $25.0 \pm 0.2^{\circ} \mathrm{C}$, respectively. Both systems contained a battery of 6 cylindrical fiberglass tanks of $250 \mathrm{~L}$ capacity each. Tanks were supplied with a continuous flow of filtered seawater $\left(6.0 \mathrm{~L} \mathrm{~min}^{-1}\right)$, salinity averaged $37.3 \pm 0.5 \%$ and dissolved oxygen was kept near to satiation.

Fish were allocated to each system and acclimatized for 15 days to the tanks and water temperatures. Thereafter, 30 fish with an average body weight of $24 \mathrm{~g}$ were randomly distributed to each tank. Each diet was assigned to triplicate groups of animals. Fish in both water systems were fed by hand twice a day, six days a week, to near satiation with one of the experimental diets during 4 weeks. Then, fish were bulk weighed and 5 fish from each tank were sampled for determination of hepatosomatic 
1 and visceral indices (sampling \#1). In order to minimise stress caused by manipulation,

2 the remaining fish were fed for 3 more days and then blood and liver from 6 fish per

3 tank were sampled six hours after the morning meal (sampling \#2).

4

Thereafter, the water temperature of the $18^{\circ} \mathrm{C}$ system was quickly raised (within 24 hours) to $25^{\circ} \mathrm{C}$ and fish continued to be fed to near satiation with the same diets during 1 more week. Then, blood and liver from 6 fish per tank submitted to the temperature change were also sampled six hours after the morning meal (sampling \#3). Blood was collected from the caudal vein, immediately centrifuged and the plasma frozen at $-20^{\circ} \mathrm{C}$ for later analysis. After collection, livers were quickly frozen in liquid nitrogen and then stored at $-80^{\circ} \mathrm{C}$ until measurement of enzymatic activities and heat shock protein 70 (HSP70) gene expression.

\subsection{Analytical methods}

\subsubsection{Proximate analysis}

Chemical analysis of the diets was conducted using the following procedures: dry matter after drying at $105^{\circ} \mathrm{C}$ until constant weight; ash by combustion in a muffle furnace at $450^{\circ} \mathrm{C}$ for $16 \mathrm{~h}$; protein content $(\mathrm{N} \times 6.25)$ by the Kjeldahl method after acid digestion using Kjeltec digestion and distillation units; lipid by petroleum ether extraction (Soxtec HT System) and gross energy by direct combustion in an adiabatic bomb calorimeter (PARR model 1261). Plasma glucose was determined using an enzymatic-colorimetric method (glucose kit, cod. 1001191; Spinreact).

\subsection{Enzyme activity}

\subsubsection{Hexokinase /glucokinase and pyruvate kinase activities}


In order to measure hexokinase (HK; EC 2.7.1.1) / glucokinase (GK; EC

2 2.7.1.11) and L-type pyruvate kinase (PK; EC 2.7.1.40) activities, a frozen sample of

3 liver (200mg) was homogenized (dilution 1 / 10) in ice-cold buffer (80mM Tris; 5mM

4 EDTA; 2mM DTT; 1mM benzamidine; 1mM 4-(2-aminoethyl) benzenesulfonyl

5 fluoride, $\mathrm{pH}$ 7.6). After centrifugation $(900 \times \mathrm{g}$ for $10 \mathrm{~min})$, the resultant supernatant

6 was separated for HK/GK and PK activity measurements. The HK (low Km HKs) and

7 GK (high Km HK or HK IV) activities were measured using $0.5 \mathrm{mM}$ and $100 \mathrm{mM}$ of

8 glucose, respectively, as described previously (Tranulis et al., 1996; Panserat et al.,

92000 a) at $37^{\circ} \mathrm{C}$ by coupling ribulose-5-phosphate formation from glucose-6-phosphate

10 to the reduction of $\beta$-NADP using purified glucose-6-phosphate dehydrogenase (Sigma)

11 and 6-phosphogluconate dehydrogenase (Sigma) as coupling enzymes. This assay for

12 measuring GK activity on frozen samples necessitated correction by measuring glucose

13 dehydrogenase (EC 1.1.1.47) activity as described by Tranulis et al. (1996). To measure

14 PK activities, the supernatant was centrifuged at $10000 \times g$ for $20 \mathrm{~min}$ and the resultant

15 cytosolic fraction was used for enzyme activity measurements. The procedure followed

16 was that of Foster and Moon (1985), monitoring the decrease in absorbance at $340 \mathrm{~nm}$

17 ( $\beta$-NAD, reduced form disappearance) using purified lactate dehydrogenase (Sigma) in

18 excess as the coupling enzyme.

\subsubsection{Fructose-1,6-bisphosphatase activities}

To measure the activity of fructose-1,6-bisphosphatase (FBPase; EC 3.1.3.11), a

22 frozen sample of liver (200mg) was homogenized (dilution 1 / 10) in ice-cold buffer

23 (20mM Tris; 5mM EDTA; 2mM DTT; 0.24mM saccharose, $\mathrm{pH}$ 8). The homogenate

24 was centrifuged at $900 \times g$ for $10 \mathrm{~min}$ and the resultant supernatant was centrifuged at 10

$25000 \times g$ for $20 \mathrm{~min}$. Enzyme assays were performed on cytosolic fractions as previously 
1 described by Tranulis et al. (1996), monitoring the increase in absorbance ( $\beta$-NADPH

2 appearance) using purified glucose-6-phosphate dehydrogenase (Sigma) and 6-

3 phosphogluconate dehydrogenase (Sigma) as coupling enzymes.

4

5 2.4.3. Glucose-6-phosphatase activities

6 In order to measure glucose-6-phosphatase (G6Pase; EC 3.1.3.9) activity,

7 microsomes were obtained from sea bass livers, as described previously (Panserat et al.,

8 2000b). Microsomes were suspended in buffer $\left(100 \mathrm{mM} \mathrm{NaH}_{2} \mathrm{PO}_{4} ; 25 \mathrm{mM} \mathrm{Na}_{2} \mathrm{HPO}_{4}\right.$;

$92 \mathrm{mM}$ EDTA; 1mM DTT, $\mathrm{pH}$ 7), without further treatment. The procedure followed was

10 that of Alegre et al. (1988), monitoring the increase in absorbance at $340 \mathrm{~nm}(\beta$-NADH

11 appearance) using purified glucose dehydrogenase (Sigma) in excess as the coupling 12 enzyme.

\subsubsection{Glucose-6-phosphate dehydrogenase activities}

For measurement of glucose-6-phosphate dehydrogenase (G6PD; EC 1.1.1.49)

activity, a frozen sample of liver (200 mg) was homogenized (dilution 1 / 5) in ice-cold buffer (0.02M Tris; 0.25M sucrose; 2mM EDTA; 0.1M NaF; 0.5mM PMSF; 0.01M $\beta$ mercapto ethanol, $\mathrm{pH}$ 7.4). Homogenates were centrifuged at $30000 \mathrm{x} g$ for $20 \mathrm{~min}$.

19 Enzyme assays were performed as previously described by Bautista et al. (1988).

\subsubsection{Specific enzyme activities}

All enzyme activities were expressed per mg of hepatic soluble protein (specific

23 activity). Protein concentration was determined according to Bradford (1976) using a

24 Sigma protein assay kit with bovine serum albumin as a standard. One unit of enzyme 
1 activity was defined as the amount of enzyme that catalysed the hydrolysis of $1 \mu \mathrm{mol}$ of

2 substrate per min under the standard conditions $\left(37^{\circ} \mathrm{C}\right)$.

3

4 2.5. HSP70 gene expression analysis: real-time polymerase chain reaction (PCR)

Total RNA was extracted from sea bass livers using TRIzol reagent (Invitrogen,

6 Carlsbad, CA) and HSP70 mRNA levels were determined by real-time RT- PCR. RNA

7 samples were treated by RQ1 RNase-Free DNase prior to RT-PCR (Promega, Madison,

8 WI), to avoid genomic DNA amplification. cDNA was generated from $1 \mu$ g DNase-

9 treated RNA using SuperScript ${ }^{\mathrm{TM}}$ III RNase H-Reverse Transcriptase (Invitrogen,

10 Carlsbad, CA). Real-time PCR was performed in the iCycler iQ ${ }^{\mathrm{TM}}$ (BIO-RAD,

11 Hercules, CA). Quantitative PCR analyses for HSP70 were performed on $10 \mu \mathrm{l}$ of the

12 diluted RT reaction mixture using the $\mathrm{iQ}^{\mathrm{TM}}$ SYBR ${ }^{\circledR}$ Green Supermix (BIO-RAD,

13 Hercules, CA). The total volume of the PCR reaction was $25 \mu$, containing $200 \mathrm{nM}$ of

14 sea bass gene specific primers (Table 2). Thermal cycling was initiated with the

15 incubation at $95^{\circ} \mathrm{C}$ for 3 minutes for hot-start iTaq ${ }^{\mathrm{TM}}$ DNA polymerase activation. 35

16 steps of PCR were performed, each one consisting of heating at $95^{\circ} \mathrm{C}$ for 20 s for

17 denaturing, and at $59^{\circ} \mathrm{C}$ for 30 s for annealing and extension. Following the final cycle

18 of the PCR, melting curves were systematically monitored (temperature gradient at

$190.5^{\circ} \mathrm{C} / 10 \mathrm{~s}$ from $55^{\circ} \mathrm{C}$ up to $94^{\circ} \mathrm{C}$ ). Relative quantification of the target gene transcript

20 (HSP70) with a chosen reference gene transcript (the sea bass elongation factor $1 \alpha$

21 (EF1 $\alpha$ ), previously used in another fish species, rainbow trout (Gabillard et al., 2003),

22 was made following the Pfaffl method with the Relative Expression Software tool

23 (RESTC) (Pfaffl, 2001; Pfaffl et al., 2002). This mathematical algorithm, which needs

24 no calibration curve, computes an expression ratio, based on real-time PCR efficiency

25 and the crossing point deviation of the sample versus a control: 


$$
\mathrm{R}=\frac{\left[\left(\mathrm{E}_{\mathrm{HSP70}}\right)^{\Delta \mathrm{CT}}{ }_{\mathrm{HSP70}} \text { (mean control - mean sample) }\right]}{\left[\left(\mathrm{E}_{\mathrm{EF} 1 \alpha}\right)^{\Delta \mathrm{CT}}{ }_{\mathrm{EF} 1 \alpha}(\text { mean control - mean sample })\right]}
$$

5 where E is PCR efficiency determined by standard curve using serial dilution of cDNA;

$6 \quad \Delta \mathrm{CT}$ the crossing point deviation of the sample versus a control.

7

\section{$8 \quad$ 2.6. Statistical analysis}

9 Data are presented as means \pm standard deviation. Statistical evaluation of the

10 results was done by one-way or two-way analysis of variance using a Statgraphics Plus

11 Version 7.0 for Windows software package. Before analysis, hepatosomatic index, GK,

12 and PK activities were log transformed for normality. A probability level of 0.05 was

13 used for rejection of the null hypothesis. Significant differences among means were

14 determined by the Tukey’s multiple range test and by the non parametric Rest statistical

15 test for HSP70 gene expression analysis. 


\section{$1 \quad 3$. Results}

2

Both feed intake and growth were significantly higher in fish held at the higher water temperature (Table 3). At $25^{\circ} \mathrm{C}$, final body weight and specific growth rate were significantly higher in fish fed diet WS than diet GLU, whereas at $18^{\circ} \mathrm{C}$ there were no significant differences between fish fed the two experimental diets. Both feed intake (g $\mathrm{kg} \mathrm{ABW}^{-1}$ day $^{-1}$ ) and feed efficiency were significantly higher at $25^{\circ} \mathrm{C}$ than at $18^{\circ} \mathrm{C}$ (Table 3). Within each temperature, feed intake was significantly higher in fish fed diet WS while feed efficiency was significantly higher in fish fed diet GLU. Protein efficiency ratio (PER) was also significantly higher in fish held at $25^{\circ} \mathrm{C}$ (Table 3). Nevertheless, within each temperature there were no significant differences in PER among groups. While at $25^{\circ} \mathrm{C}$ the visceral index (VI) was unaffected by diet composition, at $18^{\circ} \mathrm{C}$ it was significantly higher in fish fed GLU diet (Table 3). Hepatosomatic index (HSI) was significantly higher in fish held at the lower water temperature (Table 3). Within each temperature, HSI was higher in fish fed GLU diet. Plasma glucose was not significantly affected by water temperature. It was, however, higher in fish fed GLU diet than WS diet and this difference was significant at $25^{\circ} \mathrm{C}$ (Table 3). The quick rise of water temperature from $18^{\circ} \mathrm{C}$ to $25^{\circ} \mathrm{C}$ had no significant effect on plasma glucose levels (data not shown).

Within each temperature, there were no significant differences in HK and G6Pase activities among groups (Table 4). There was also no effect of temperature on HK and G6Pase activities. On the contrary, significant variations were noticed for the other enzymes studied. Indeed, GK, FBPase and G6PD activities were significantly higher at $25^{\circ} \mathrm{C}$ than at $18^{\circ} \mathrm{C}$ (Table 4) while there was no effect of temperature on PK 
1 (Table 4). Within each temperature, GK, PK and G6PD activities were significantly

2 higher in fish fed GLU diet while FBPase activity was higher in fish fed WS diet,

3 although this latter difference was only significant in fish kept at $18^{\circ} \mathrm{C}$.

4

The effect of a rise in water temperature from $18^{\circ} \mathrm{C}$ to $25^{\circ} \mathrm{C}$ on hepatic

6 glycolytic/gluconeogenic and lipogenic enzyme activities is present in Fig. 1. In fish fed

7 both diets and submitted to temperature shock, activities of HK, GK, FBPase and

8 G6Pase were not different from those of groups maintained at $25^{\circ} \mathrm{C}$ for the whole

9 period. PK activity significantly increased after the heat shock in fish fed both diets and

10 was significantly higher than in fish previously acclimated to $25^{\circ} \mathrm{C}$. G6PD activity in

11 fish fed diet GLU, but not diet WS, was significantly lower in the group submitted to

12 the heat shock in comparison to the $25^{\circ} \mathrm{C}$ acclimated fish.

In fish fed diet WS, there were no differences in hepatic HSP70 gene expression (Table 5). In contrast, in fish fed diet GLU, even though there were also no differences 16 in hepatic HSP70 gene expression between fish raised at $25^{\circ} \mathrm{C}$ and at $18^{\circ} \mathrm{C}$ (Table 5), 17 HSP70 gene expression was found to be lower in fish submitted to the temperature shock $\left(18^{\circ} \mathrm{C}\right.$ to $\left.25^{\circ} \mathrm{C}\right)$ in comparison to fish acclimated to $25^{\circ} \mathrm{C}$ or $18^{\circ} \mathrm{C}$, respectively. 


\section{4. Discussion}

2

4 similar in both cold water $\left(18^{\circ} \mathrm{C}\right)$ and warm water $\left(25^{\circ} \mathrm{C}\right)$ acclimated sea bass, which

5 suggests that HSP70 gene expression is not associated to the rearing temperature per se.

6 In contrast, in silver sea bream, Deane and Woo (2005) observed that acclimation to

7 cold temperature $\left(12^{\circ} \mathrm{C}\right)$ during one month resulted in an up regulation of HSP70 in

8 comparison to fish at $25^{\circ} \mathrm{C}$. However, one week after heat shock $\left(18^{\circ} \mathrm{C}\right.$ to $\left.25^{\circ} \mathrm{C}\right) \mathrm{a}$

9 down-regulation of HSP70 gene expression in comparison to fish acclimated to $25^{\circ} \mathrm{C}$ or

$1018^{\circ} \mathrm{C}$ was observed in fish fed the GLU diet (but not with the WS diet for unknown 11 reasons). Indeed, Ojima et al. (2005) and Cara et al. (2005) observed also a variation of 12 HSP70 gene expression after an increase of temperature in trout cells and gilthead 13 seabream respectively. Thus, our data suggest that HSP70 may be a good bio-marker in 14 sea bass, as in other species, for an acute modification of rearing temperature. We 15 discuss now the effects of water temperature on growth and metabolism in European sea 16 bass.

As expected, and irrespective of carbohydrate source, results of the present study showed that the increase of water temperature $\left(18^{\circ} \mathrm{C}\right.$ vs. $\left.25^{\circ} \mathrm{C}\right)$ significantly improved growth performance, feed efficiency, as well as protein efficiency ratio in sea bass juveniles. Similar results were already reported for this species (Alliot et al., 1983; Hidalgo et al., 1987; Peres and Oliva-Teles, 1999; Person-Le Ruyet et al., 2004) and for other species such as trout (Cho and Slinger, 1979; Cho and Watanabe, 1985; Alanara, 1994; Capilla et al., 2003) and carp (Goolish and Adelman, 1984). 
At $25^{\circ} \mathrm{C}$, growth of fish fed the starch diet was better than that of fish fed the

2 glucose diet. At $18^{\circ} \mathrm{C}$ such a difference was not evident due to the poor growth of both

3 groups at that temperature. The poor ability to utilize simple carbohydrates was also

4 observed in other fish species such as tilapia (Anderson et al., 1984; Shiau and Peng,

5 1993), sunshine bass (Hutchins et al., 1998), common carp and red sea bream (Furuichi

6 and Yone, 1982). Dietary glucose is rapidly absorbed across the gut comparatively to

7 complex carbohydrates such as starch (Lin and Shiau, 1995). It has been suggested that

8 in fish fed glucose rich diets a considerable amount of glucose may enter the blood

9 before adequate insulin levels are available to allow its utilization at cellular level

10 (Pieper and Pfeffer, 1980a; Furuichi and Yone, 1981). Complementary data on plasma

11 insulin profiles in European sea bass might be of use.

Several authors have observed that yellowtail (Furuichi, 1983), hybrid tilapia

14 (Shiau and Peng, 1993), Indian major carp (Erfanullah and Jafri, 1995), common carp

15 (Shikata et al., 1994), grouper (Shiau and Lin, 2001) and silver perch (Stone, 2003)

16 utilize complex carbohydrates, such as gelatinized starch or dextrin, more efficiently

17 than glucose to spare protein for growth. But, in the present study, data on protein

18 efficiency ratio suggest that in sea bass there is a similar protein sparing effect of both

19 carbohydrates, irrespective of water temperature.

Plasma glucose levels six hours after feeding were affected by dietary

22 carbohydrate source. Indeed, plasma glucose concentration was higher in sea bass fed

23 diet GLU than diet WS, and this difference was significant at $25^{\circ} \mathrm{C}$. Similar results

24 regarding carbohydrate source were previously observed in rainbow trout (Bergot,

25 1979b; Brauge et al., 1994) and in tilapia (Shiau and Liang, 1995). However, contrary to 
1 what was reported for rainbow trout (Brauge et al., 1995), we did not found any specific

2 effect of temperature on plasma glucose levels. Thus, carbohydrate source seems to be

3 the major factor controlling glycaemia values in sea bass.

4

At both water temperatures, HK activity was unaffected by carbohydrate source,

6 confirming that also in European sea bass this enzyme is not under nutritional regulation

7 like in rainbow trout, gilthead seabream, common carp (Panserat et al., 2000a) and

8 hybrid tilapia (Oreochromis niloticus x O. aureus) (Lin and Shiau, 1995). Nevertheless,

9 we observed that HK activity is lower when compared with activities found in other

10 finfish fed similar level of carbohydrates (Panserat et al., 2000a; Kirchner et al., 2003a).

11 HK activity was also unaffected by rearing temperature as well as by heat shock as was

12 previously observed in rainbow trout by Tranulis et al. (1991). However, also in

13 rainbow trout, a higher activity of $\mathrm{HK}$ at $18^{\circ} \mathrm{C}$ than at $8^{\circ} \mathrm{C}$ was recently reported (Capilla

14 et al., 2003).

15 Irrespective of water temperature, dietary glucose does appear to induce GK and

16 PK more than starch. This may be related to the higher glycaemia in fish fed diet GLU,

17 which may possibly induce the liver capacity to store excess glucose as it was observed

18 in rainbow trout (Panserat et al., 2001; Kirchner et al., 2003b). In fact, HSI was higher

19 in fish fed GLU diet which may be due to higher glycogen content. There was also a

20 positive effect of temperature on GK activity but not on PK. Moreover, after the heat

21 shock, GK activity quickly raised to values previously found at $25^{\circ} \mathrm{C}$ indicating that

22 there was a rapid adaptation of liver glucose metabolism to the higher feed intake, and

23 consequent increased glucose supply. In contrast, in response to heat shock, PK

24 activities raised to values significantly higher than those previously found at $25^{\circ} \mathrm{C}$, 
1 suggesting a transitory compensation or up-regulation associated with a temporary

2 metabolic reorganization in the fish (Tranulis et al., 1991).

3

Data on the effect of temperature on hepatic gluconeogenesis in fish are scarce and 5 discordant (Woo, 1990; Shikata et al., 1995).We found here, a significant effect of

6 carbohydrate source and water temperature on the activity of FBPase but not that of

7 G6Pase. In fact the starch-based diet led to higher FBPase activity than the glucose diet,

8 in contrast to what was previously reported for hybrid tilapia (Shikata et al., 1994).

9 Moreover, FBPase activity was significantly higher in the warm-acclimated fish

10 suggesting an enhanced gluconeogenic activity at higher temperature. After the heat

11 shock, FBPase activity was not significantly different from values found in sea bass

12 previously reared at $25^{\circ} \mathrm{C}$, suggesting that for FBPase, as it was observed for $\mathrm{GK}$, one

13 week was long enough for a metabolic reorganization in relation to temperature change.

In the present study, and irrespective of water temperature, G6PD activity in sea

16 bass fed the glucose diet was significantly higher than in fish fed the starch diet. This

17 may be associated to the higher glycemia observed in this group which enhanced

18 lipogenesis. Similar results were already reported in sturgeon (Hung et al., 1989),

19 rainbow trout (Hung and Storebakken, 1994) and common carp (Shikata et al., 1994).

20 While rearing temperature had no effect on G6PD activity in fish fed diet WS, in fish

21 fed diet GLU, G6PD activity was significantly higher in the warm-acclimated fish,

22 indicating a higher lipogenic activity at higher temperatures in this group. This may be

23 due to the higher feed intake (i.e. glucose) recorded in fish reared at $25^{\circ} \mathrm{C}$. Tranulis et al.

24 (1991) also reported no differences in G6PD activity of rainbow trout reared at $0-2^{\circ} \mathrm{C}$ or

25 at $10-17^{\circ} \mathrm{C}$ and fed a $16 \%$ carbohydrate diet. One week after the heat shock G6PD 
1 activity remained similar to that observed in fish reared at $18^{\circ} \mathrm{C}$. This suggests a longer

2 adaptation period to water temperature changes for G6PD as compared to glycolytic

3 (GK and PK) and gluconeogenic (FBPase) enzymes.

4

5 In conclusion, carbohydrate source and water temperature are important factors in 6 regulation of carbohydrates metabolism in sea bass juveniles. Thus, fish fed a glucose 7 diet or reared at high temperatures $\left(25^{\circ} \mathrm{C}\right)$ presented enhanced liver glycolytic, lipogenic 8 and gluconeogenic capacities compared to fish fed a starch diet or reared at low 9 temperatures $\left(18^{\circ} \mathrm{C}\right)$. Overall, the present data showed that one week seems to be 10 sufficient for a metabolic reorganization to occur in sea bass submitted to a sudden rise 11 in temperature of $7^{\circ} \mathrm{C}$ in $24 \mathrm{~h}$. 


\section{Acknowledgements}

2 This work was partially sponsored by GRICES. The first author was supported 3 by a grant (BD/11414/2002) from Fundação para a Ciência e a Tecnologia, Portugal.

4 We would like to express our thanks to P. Correia for the assistance during the growth 5 trial and M.L. Faria for the gross energy analysis. We also acknowledge E. Plagnes-

6 Juan and C. Vachot for their technical assistance in molecular and enzymatic analysis, 7 respectively. 


\section{References}

2 Alanara, A., 1994. The effect of temperature, dietary energy content and reward level on

3 the demand feeding activity of rainbow trout (Oncorhynchus mykiss). Aquaculture 126, $4 \quad 349-359$.

5

6 Alegre, M., Ciudad, C.J., Fillat, C., Guinovart, J.J., 1988. Determination of glucose-67 phosphatase activity using the glucose-dehydrogenase-coupled reaction. Anal. 8 Biochem. 173, 185-189.

9

10 Alliot, E., Febvre, A., Metailler, R., Pastoureaud, A., 1974. Besoins nutritifs du bar 11 (Dicentrarchus labrax L.). Etude du taux de protéine et du taux de lipid dans le régime. 12 Actes de Colloque CNEXO 1, 215-228.

14 Alliot, E., Pastoureaud, A., Nedelec, J., 1979. Etude de l'apport calorique et du rapport 15 calorico-azoté dans l'alimentation du bar, Dicentrarchus labrax. Influence sur la 16 croissance et la composition corporelle. Proc. World Symp. on Finfish Nutrition and 17 Fishfeed Technology, Hamburg, pp. 241-251.

19 Alliot, E., Pastoureaud, A., Thebault, H., 1983. Influence de la température et de la 20 salinité sur la croissance et la composition corporelle d'alevins de Dicentrarchus labrax. 21 Aquaculture 31, 181-194. 
1 Alliot, E., Pastoureaud, A., Thebault, H., 1984. Amelioration des formules d'aliments

2 artificiels chez le loup (Dicentrarchus labrax). II. Utilisation des glucides. Recherches

3 Biologiques en Aquaculture 1, 87-94.

4

5 Anderson, J., Jackson, A.J., Capper, B.B., 1984. Effects of dietary carbohydrate and

6 fiber on the tilapia, Oreochronis niloticus (Linn.). Aquaculture 37, 303-314.

7

8 Basu, N., Todgham, A.E., Ackerman, P.A., Bibeau, M.R., Nakano, K., Schulte, P.M.,

9 Iwama, G.K., 2002. Heat shock protein genes and their functional significance in fish.

10 Gene 295, 173-183.

11

12 Bautista, J.M., Garrido-Pertierra, A., Soler, G., 1988. Glucose-6-phosphate 13 dehydrogenase from Dicentrarchus labrax liver: kinetic mechanism and kinetics of 14 NADPH inhibition. Biochim. Biophys. Acta 967, 354-363.

15

16 Bergot, F., 1979a. Carbohydrate in rainbow trout diets: effects of the level and source of 17 carbohydrate and the number of meals on growth and body composition. Aquaculture 18 18, 157-167.

19

20 Bergot, F., 1979b. Effects of dietary carbohydrates and their mode of distribution on

21 glycaemia in rainbow trout (Salmo gairdneri Richardson). Comp. Biochem. Physiol.

22 64A, 543-547. 
1 Bergot, F., 1993. Digestibility of natives starches of various botanical origins by

2 rainbow trout (Oncorhynchus mykiss). In: Kaushik, S.J., Luquet, P. (Eds.), Fish

3 Nutrition in Practice, Biarritz, France, pp. 857-865.

4

5 Bradford, M.M., 1976. A rapid and sensitive method for the quantification of 6 microgram quantities of protein utilizing the principle of protein-dye binding. Anal. $7 \quad$ Biochem. 72, 248-254.

8

9 Brauge, C., Médale, F., Corraze, G., 1994. Effect of dietary carbohydrate levels on 10 growth, body composition and glycaemia in rainbow trout, Oncorhynchus mykiss, 11 reared in seawater. Aquaculture 123, 109-120.

13 Brauge, C., Corraze, G., Médale, F., 1995. Effect of dietary levels of lipid and 14 carbohydrate on growth performance, body composition, nitrogen excretion and plasma 15 glucose levels in rainbow trout reared at 8 or $18{ }^{\circ} \mathrm{C}$. Reprod. Nutr. Develop. 35, 27716290.

18 Capilla, E., Médale, F., Navarro, I., Panserat, S., Vachot, C., Kaushik, S., Gutiérrez, J., 19 2003. Muscle insulin binding and plasma levels in relation to liver glucokinase activity, 20 glucose metabolism and dietary carbohydrates in rainbow trout. Regulatory Peptides 21 110, 123-132. 
1 Cara, J.B., Aluru, N., Moyano, F.J., Vijayan, M.., 2005. Food-deprivation induces

2 HSP70 and HSP90 protein expression in larval gilthead sea bream and rainbow trout.

3 Comp. Biochem. Physiol. Part B 142, 426-431.

4

5 Cho, C.Y., Slinger, S.J., 1979. Effect of water temperature on energy utilization in 6 rainbow trout (Salmo gairdneri). In: Mount, L.E. (Ed.), Proc. 8th Symp. on Energy 7 Metabolism. Butterworth, London, pp. 287-291.

8

9 Cho, C.Y., Watanabe, T., 1985. Dietary energy and lipid requirements of rainbow trout 10 (Salmo gairdneri) at different water temperatures. In: Moe, P.W., Tyrrell, H.F., 11 Reynolds, P.J. (Eds.), Proc. 10th Symp. on Energy Metabolism of Farm Animals. 12 EAAO 32, 206-209.

14 Cho, C.Y., Kaushik, S.J., 1990. Nutritional energetics in fish: energy and protein 15 utilization in rainbow trout (Salmo gairdneri). World. Rev. Nutr. Diet. 61, 132-172.

17 Deane, E.E., Woo, N.Y.S., 2005. Cloning and characterization of the hsp70 multigene 18 family from silver sea bream: Modulated gene expression between warm and cold 19 temperature acclimation. Biochem. Biophys. Res. Commun. 330, 776-783.

21 Deng, D.-F., Hemre, G.-I., Storebakken, T., Shiau, S.-Y., Hung, S.S.O., 2005.

22 Utilization of diets with hydrolyzed potato starch, or glucose by juvenile white sturgeon 23 (Acipenser transmontanus), as affected by Maillard reaction during feed processing. 24 Aquaculture 248, 103-109. 
1 Dias, J., Alvarez, M.J., Diez, A., Arzel, J., Corraze, G., Bautista, J.M., Kaushik, S.J.,

2 1998. Regulation of hepatic lipogenesis by dietary protein/energy in juvenile European

3 seabass (Dicentrarchus labrax). Aquaculture 161, 169-186.

4

5 Enes P, Panserat S, Kaushik S, Oliva-Teles A., 2005. Effect of normal and waxy maize

6 starch on growth, food utilization and hepatic glucose metabolism in European sea bass

7 (Dicentrarchus labrax) juveniles. Comp. Biochem. Physiol. Part A (in press).

8

9 Erfanullah, Jafri, A.K., 1995. Protein-Sparing Effect of Dietary Carbohydrate in Diets

10 for Fingerling Labeo Rohita. Aquaculture 136, 331-339.

12 Foster, G.D., Moon, T.W., 1985. Enzyme activities in Atlantic hagfish, Myxine 13 glutinosa: changes with capacity and food deprivation. Can. J. Zool. 64, 1080-1085.

14

15 Furuichi, M., Yone, Y., 1981. Change of blood sugar and plasma insulin levels of fishes 16 in glucose tolerance test. Bull. Jp. Soc. Sci. Fish. 47, 761-764.

18 Furuichi, M., Yone, Y., 1982. Availability of carbohydrate in nutrition of carp and red 19 sea bream. Bull. Jp. Soc. Sci. Fish. 48, 945-948.

20

21 Furuichi, M., 1983. Studies on the utilization of carbohydrate by fishes. Report of the Fish Research Laboratory, Kyusbu University 6, 1-59. 
1 Furuichi, M., Taira, H., Yone, Y., 1986. Availability of carbohydrate in nutrition of

2 yellowtail. Bull. Jp. Soc. Sci. Fish. 52, 99-102.

3

4 Gabillard, J.C., Duval, H., Cauty, C., Rescan, P.Y., Weil, C., Le Bail, P.Y., 2003.

5 Differential expression of the two GH genes during embryonic development of rainbow

6 trout O. mykiss in relation with the IGFs system. Mol. Reprod. Dev. 64, 32-40.

7

8 Goolish, E.M., Adelman, I.R., 1984. Effects of ration size and temperature on the

9 growth of juvenile common carp (Cyprinus carpio L.). Aquaculture 36, 27-35.

10

11 Gornati, R., Papis, E., Rimoldi, S., Terova, G., Saroglia, M., Bernardini, G., 2004.

12 Rearing density influences the expression of stress-related genes in sea bass

13 (Dicentrarchus labrax L.). Gene 341, 111-118.

15 Gouveia, A., Oliva-Teles, A., Gomes, E., Peres, M.H., 1995. The effect of two dietary 16 levels of raw and gelatinized starch on growth and food utilization by the European 17 seabass. In: Castelló, I., Orvay, F., Calderer, I., Reig, A. (Eds.), Proc. of the Fifth 18 National Congress on Aquaculture, Univ. Barcelona, Spain, pp. 516-521.

19

20 Hidalgo, F., Alliot, E., Thebault, H., 1987. Influence of water temperature on food 21 intake, food efficiency and gross composition of juvenile sea bass, Dicentrarchus 22 labrax. Aquaculture 64, 199-207. 
1 Hidalgo, F., Alliot, E., 1988. Influence of water temperature on protein requirement and

2 protein utilization in juvenile sea bass, Dicentrarchus labrax. Aquaculture 72, 115-129.

3

4 Hung, S.S.O., Fynn-Aikins, F.K., Lutes, P.B., Xu, R., 1989. Ability of juvenile white

5 sturgeon (Acipenser transmontanus) to utilize different carbohydrate sources. J. Nutr. $6 \quad$ 119, 727-733.

7

8 Hung, S.S.O., Storebakken, T., 1994. Carbohydrate Utilization by Rainbow Trout Is

$9 \quad$ Affected by Feeding Strategy. J. Nutr. 124, 223-230.

11 Hutchins, C.G., Rawles, S.D., Gatlin III, D.M., 1998. Effects of dietary carbohydrate

12 kind and level on growth, body composition and glycemic response of juvenile sunshine

13 bass (Morone chrysops female x M. saxatilis male). Aquaculture 161, 187-199.

14

15 Jobling, M., 1994. Fish Bioenergetics. In: Fish and Fisherires Series 13, Chapman \& 16 Hall, London, pp. 213-230.

18 Kaushik, S.J., Médale, F., 1994. Energy requirements, utilization and dietary supply to 19 salmonids. Aquaculture 124, 81-97.

20

21 Kirchner S., Kaushik S., Panserat S., 2003a Effect of partial substitution of dietary 22 protein by a single gluconeogenic dispensable amino acid on hepatic glucose 
1 metabolism in rainbow trout (Oncorhynchus mykiss). Comp. Biochem. Physiol. Part A

2 134/2, 337-347.

3

4 Kirchner, S., Kaushik, S., Panserat, S., 2003b. Low protein intake is associated with

5 reduced hepatic gluconeogenic enzyme expression in rainbow trout (Oncorhynchus

6 mykiss). J. Nutr. 133, 2561-2564.

7

8 Lanari, D., Poli, B.M., Ballestrazzi, R., Lupi, P., D’Agaro, E., Mecatti, M., 1999. The

9 effects of dietary fat and NFE levels on growing European sea bass (Dicentrarchus

10 labrax L.). Growth rate, body and fillet composition, carcass traits and nutrient retention

11 efficiency. Aquaculture 179, 351-364.

12

13 Lin, J.S., Shiau, S.Y., 1995. Hepatic Enzyme Adaptation to Different Dietary

14 Carbohydrates in Juvenile Tilapia Oreochromis Niloticus X O. Aureus. Fish Physiology

15 \& Biochemistry 14, 165-170.

17 Ojima, N., Yamashita, M., Watabe, S., 2005. Quantitative mRNA expression profiling 18 of heat-shock protein families in rainbow trout cells. Biochem. Biophys. Res. Commun. $19329,51-57$.

21 Panserat, S., Médale, F., Blin, C., Brèque, J., Vachot, C., Plagnes-Juan, E., Gomes, E., 22 Krishnamoorthy, R., Kaushik, S., 2000a. Hepatic glucokinase is induced by dietary 
1 carbohydrates in rainbow trout (Oncorhynchus mykiss), gilthead seabream (Sparus

2 aurata), and common carp (Cyprinus carpio). Am. J. Physiol. 278, R1164-R1170.

3

4 Panserat, S., Médale, F., Breque, J., Kaushik, S., 2000b. Lack of significant long-term

5 effect of dietary carbohydrates on hepatic glucose-6-phosphatase expression in rainbow

6 trout (Oncorhynchus mykiss). J. Nutr. Biochem. 11, 22-29.

7

8 Panserat, S., Capilla, E., Gutierrez, J., Frappart, P.O., Vachot, C., Plagnes Juan, E.,

9 Aguirre, P., Breque, J., Kaushik, S., 2001. Glucokinase is highly induced and glucose-6-

10 phosphatase poorly repressed in liver of rainbow trout (Oncorhynchus mykiss) by a

11 single meal with glucose. Comp. Biochem. Physiol. 128B, 275-283.

13 Peres, H., Oliva-Teles, A., 1999. Influence of temperature on protein utilization in 14 juvenile European seabass (Dicentrarchus labrax). Aquaculture 170, 337-348.

16 Peres, H., Oliva-Teles, A., 2002. Utilization of raw and gelatinized starch by European 17 sea bass (Dicentrarchus labrax) juveniles. Aquaculture 205, 287-299.

18 Person -Le Ruyet, J., Mahé, K., Le Bayon, N., Le Delliou, H., 2004. Effects of 19 temperature on growth and metabolism in a Mediterranean population of European sea 20 bass, Dicentrarchus labrax. Aquaculture 237, 269-280.

22 Pfaffl, M.W., 2001. A new mathematical model for relative quantification in real-time RT-PCR. Nucleic Acids Res. 29 (9), 2002-2007. 
1 Pfaffl, M.W., Horgan, G.W., Dempfle, L., 2002. Relative expression software tool

2 (RESTC) for group-wise comparison and statistical analysis of the relative expression

3 results in real-time PCR. Nucleic Acids Res. 30 (9), 1-10.

4

5 Pfeffer, E., Beckmann-Toussaint, J., Henrichfreise, B., Jansen, H.D., 1991. Effect of 6 extrusion on efficiency of utilization of maize starch by rainbow trout (Oncorhynchus 7 mykiss). Aquaculture 96, 293-303.

9 Pieper, A., Pfeffer, E., 1980a. Studies on the comparative efficiency of utilization of 10 gross energy from some carbohydrates, proteins and fats by rainbow trout (Salmo 11 gairdneri, R.). Aquaculture 20, 323-332.

13 Pieper, A., Pfeffer, E., 1980b. Studies on the effect of increasing proportions of sucrose 14 or gelatinized maize starch in diets for rainbow trout (Salmo gairdneri, R.) on the 15 utilization of dietary energy and protein. Aquaculture 20, 333-342.

17 Sánchez-Muros, M.J., García-Rejón, L., García-Salguero, L., laHiguera, M., Lupiáñez, 18 J.A., 1998. Long-term nutritional effects on the primary liver and kidney metabolism in 19 rainbow trout. Adaptive response to starvation and a high-protein, carbohydrate-free 20 diet on glutamate dehydrogenase and alanine aminotransferase kinetics. Inter. J. 21 Biochm. Cell Biol. 30, 55-63. 
1 Shiau, S.Y., Peng, C.Y., 1993. Protein-sparing effect by carbohydrate in diets for

2 tilapia, Oreochromis niloticus x O. aureus. Aquaculture 117, 327-334.

3

4 Shiau, S.Y., Liang, H.S., 1995. Carbohydrate utilization and digestibility by tilapia,

5 Oreochromis niloticus x O. aureus, are affected by chromic oxide inclusion in the diet.

$6 \quad$ J. Nutr. 125, 976-982.

7

8 Shiau, S.Y., Lin, Y.H., 2001. Carbohydrate utilization and its protein-sparing effect in

9 diets for grouper (Epinephelus malabaricus). Anim. Sci. 73, 299-304.

11 Shikata, T., Iwanaga, S., Shimeno, S., 1994. Effects of dietary glucose, fructose, and

12 galactose on hepatopancreatic enzyme activities and body composition in carp. Fish.

13 Sci. 60, 613-617.

14

15 Shikata, T., Iwanaga, S., Shimeno, S., 1995. Metabolic response to acclimation 16 temperature in carp. Fish. Sci. 61 (3), 512-516.

17

18 Stone, D.A.J., 2003. Dietary carbohydrate utilization by fish. Rev. Fish. Sci. 11, 33719369. 
1 Tian, L.-X., Liu, Y.-J., 2004. Utilization of glucose and cornstarch by juvenile grass

2 carp. North American Journal of Aquaculture 66, 141-145.

3

4 Tranulis, M.A., Christophersen, B., Blom, A.K., Borrebaek, B., 1991. Glucose

5 dehydrogenase, glucose-6-phosphate dehydrogenase and hexokinase in liver of rainbow

6 trout (Salmo gairdneri). Effects of starvation and temperature variations. Comp.

$7 \quad$ Biochem. Physiol., 99B, 687-691.

8

9 Tranulis, M.A., Dregni, O., Christophersen, B., Krogdahl, A., Borrebaek, B., 1996. A

10 glucokinase-like enzyme in the liver of Atlantic salmon (Salmo salar). Comp. Biochem.

11 Physiol. 114B, 35-39.

12 Wilson, R.P., 1994. Utilization of dietary carbohydrate by fish. Aquaculture 124, 67-80.

13

14 Woo, N.Y.S., 1990. Metabolic and osmoregulatory changes during temperature

15 acclimation in the red sea bream, Chrysophrys major: Implications for its culture in the

16 subtropics. Aquaculture 87, 197-208. 
Table 1

Composition and proximate analyses of the experimental diets

\begin{tabular}{|c|c|c|}
\hline & \multicolumn{2}{|l|}{ Diets } \\
\hline & WS & GLU \\
\hline \multicolumn{3}{|l|}{ Ingredients (\% dry weight) } \\
\hline Fish meal $^{a}$ & 58.7 & 58.7 \\
\hline Soluble fish protein concentrate ${ }^{b}$ & 5.0 & 5.0 \\
\hline Cod liver oil & 11.9 & 11.9 \\
\hline Waxy maize starch ${ }^{c}$ & 20.9 & - \\
\hline D-Glucose & - & 20.9 \\
\hline Vitamin premix ${ }^{d}$ & 1.0 & 1.0 \\
\hline Mineral premix ${ }^{\mathrm{e}}$ & 1.0 & 1.0 \\
\hline Choline chloride $(60 \%)$ & 0.5 & 0.5 \\
\hline Carboxymethylcellulose & 1.0 & 1.0 \\
\hline \multicolumn{3}{|l|}{ Proximate analyses (\% dry weight) } \\
\hline Dry matter & 92.3 & 90.2 \\
\hline Crude protein & 47.2 & 49.4 \\
\hline Crude fat & 17.7 & 17.7 \\
\hline Ash & 11.4 & 12.1 \\
\hline Gross energy ( $\left.\mathrm{KJ} \mathrm{g}^{-1} \mathrm{DM}\right)$ & 22.4 & 23.1 \\
\hline
\end{tabular}

${ }^{a}$ Pesqueira Diamante, Steam Dried LT, Spain (CP: 75.3\% DM; GL: 8.8\% DM)

${ }^{\mathrm{b}}$ Sopropèche G, France (CP: 75.4\% DM ; GL : 19.2\%DM).

${ }^{\mathrm{C}}$ Cerestar (Mechelen, Belgium)

${ }^{d}$ Vitamins ( $\mathrm{mg} \mathrm{Kg}^{-1}$ diet): retinol acetate, 18000 (IU Kg ${ }^{-1}$ diet); cholecalciferol, 2000 (IU Kg ${ }^{-1}$ diet); alpha tocopherol acetate, 35; sodium menadione bisulphate, 10; thia min- $\mathrm{HCl}, 15$; riboflavin, 25; calcium pantothenate, 50; nicotinic acid, 200; pyridoxine $\mathrm{HCl}$, 5; folic acid, 10; cyanocobalamin, 0.02; biotin, 1.5; ascorbic acid, 50; inositol, 400.

${ }^{\mathrm{e}}$ Minerals ( $\mathrm{mg} \mathrm{Kg}^{-1}$ diet): cobalt sulphate, 1.91; copper sulphate, 19.6; iron sulphate 200; sodium fluoride, 2.21; potassium iodide; 0.78 ; magnesium oxide; 830; manganese oxide, 26; sodium selenite, 0.66 ; zinc oxide, 37.5; dibasic calcium phosphate, $5.93\left(\mathrm{~g} \mathrm{Kg}^{-1}\right.$ diet); potassium chloride, 1.15 (g Kg${ }^{-1}$ diet); sodium chloride, 0.40 ( $\mathrm{g} \mathrm{Kg}^{-1}$ diet). 
Table 2

Nucleotides sequences of the PCR primers used to assay gene expression by real-time quantitative PCR

\begin{tabular}{lllcc}
\hline & Forward primer & Reverse primer & $\begin{array}{l}\text { Annealing } \\
\text { temperature }\left({ }^{\circ} \mathrm{C}\right)\end{array}$ & $\begin{array}{l}\text { PCR produt } \\
\text { length }(\mathrm{pb})\end{array}$ \\
\hline HSP70 & gtctggacaaaggcaagagc & cacaaagtggttgaccatgc & $55^{\circ} \mathrm{C}$ & 176 \\
EF1a & cccctggacacagagacttc & ttgactccaacgatgagctg & $54^{\circ} \mathrm{C}$ & 184 \\
\hline
\end{tabular}

1 Sea bass HSP70 gene - genbank accession number: AY423555

2 Sea bass EF1 $\alpha$ gene - genbank accession number: AJ866727

3

4

5

6

7

8

9

10

11

12

13

14

15

16

17

18

19

20

21

22

23

24

25

26

27

28

29

30

31 
Table 3

Growth performance, feed utilization efficiency, visceral and hepatic index and plasmatic glucose of sea bass fed the experimental diets during 4 weeks (Initial $\mathrm{VI}=10.5$; Initial $\mathrm{HSI}=1.5$ )

\begin{tabular}{|c|c|c|c|c|}
\hline \multirow{2}{*}{$\begin{array}{l}\text { Temperature } \\
\text { Diets }\end{array}$} & \multicolumn{2}{|c|}{$25^{\circ} \mathrm{C}$} & \multicolumn{2}{|c|}{$18^{\circ} \mathrm{C}$} \\
\hline & WS & GLU & WS & GLU \\
\hline Initial body weight (IBW), g & 24.0 & $24.0 \pm 0.02$ & 24.0 & 24.0 \\
\hline Final body weight (FBW), g & $39.2 \pm 0.4^{\mathrm{a}}$ & $36.2 \pm 0.8^{b}$ & $30.3 \pm 0.8$ & $29.7 \pm 1.0$ \\
\hline Feed intake ( $\mathrm{g} \mathrm{kg} \mathrm{ABW}^{-1}$ day $^{-1}$ ) & $21.3 \pm 0.4^{\mathrm{a}}$ & $16.5 \pm 1.1^{b}$ & $13.3 \pm 0.8^{\mathrm{a}}$ & $10.2 \pm 0.8^{b}$ \\
\hline Specific growth rate $(\%)^{1}$ & $1.8 \pm 0.04^{\mathrm{a}}$ & $1.5 \pm 0.08^{\mathrm{b}}$ & $0.8 \pm 0.09$ & $0.8 \pm 0.1$ \\
\hline Feed efficiency $^{2}$ & $0.8 \pm 0.01^{\mathrm{a}}$ & $0.9 \pm 0.03^{b}$ & $0.6 \pm 0.04^{\mathrm{a}}$ & $0.7 \pm 0.06^{b}$ \\
\hline Protein efficiency ratio ${ }^{3}$ & $1.7 \pm 0.03$ & $1.8 \pm 0.06$ & $1.3 \pm 0.09$ & $1.5 \pm 0.13$ \\
\hline $\mathrm{VI}^{4}$ & $10.4 \pm 1.4$ & $11.3 \pm 1.5$ & $10.3 \pm 1.3^{\mathrm{a}}$ & $11.9 \pm 2.1^{b}$ \\
\hline $\mathrm{HSI}^{5}$ & $1.5 \pm 0.3^{\mathrm{a}}$ & $2.4 \pm 0.5^{b}$ & $2.1 \pm 0.4^{\mathrm{a}}$ & $3.4 \pm 1.0^{\mathrm{b}}$ \\
\hline Plasma glucose $\left(\mathrm{mmol} \mathrm{I}{ }^{-1}\right)$ & $6.9 \pm 1.7^{\mathrm{a}}$ & $9.5 \pm 1.6^{\mathrm{b}}$ & $8.9 \pm 3.8$ & $11.8 \pm 4.7$ \\
\hline
\end{tabular}

Two-way ANOVA

\begin{tabular}{|c|c|c|c|}
\hline Variation source $^{6}$ & Diet & Temperature & Interaction \\
\hline Final body weight (FBW), g & ** & $\star \star \star ~$ & * \\
\hline Feed intake ( $\mathrm{g} \mathrm{kg} \mathrm{ABW}^{-1} \mathrm{day}^{-1}$ ) & 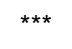 & *** & ns \\
\hline Specific growth rate (\%) & ** & *** & ns \\
\hline Feed efficiency & ** & $* * *$ & ns \\
\hline Protein efficiency ratio & * & *** & ns \\
\hline VI & ** & ns & ns \\
\hline $\mathrm{HSI}$ & $\star \star \star ~$ & 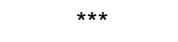 & ns \\
\hline Plasma glucose $\left(\mathrm{mmol} \mathrm{I}^{-1}\right)$ & * & ns & ns \\
\hline
\end{tabular}

4 ABW: average body weight (initial body weight + final body weight) / 2 .

5 Values are means \pm S.D. . At each temperature, means in the same line with different superscript letters are significantly different (Tukey test, $\mathrm{P}<0.05)$.

${ }^{1}$ Specific growth rate: ((In(FBW)-In(IBW) / (time in days)) $\times 100$.

${ }^{2}$ Feed efficiency: wet weight gain / dry feed intake.

${ }^{3}$ Protein efficiency ratio: wet weight gain / crude protein intake.

${ }^{4} \mathrm{VI}$ Visceral index: (viscera weight/body weight) $\times 100$.

${ }^{5} \mathrm{HSI}$ Hepatossomatic index: /liver weight/body weight) $\times 100$.

${ }^{6}{ }^{*} \mathrm{P}<0.05 ;{ }^{*} \mathrm{P}<0.01 ;{ }^{* *} \mathrm{P}<0.001 ;$ ns: non-significant. 
1 Table 4

2 Hepatic glycolytic (hexokinase, glucokinase and pyruvate kinase), gluconeogenic (fructose-1,6-bisphosphatase and 3 glucose-6-phosphatase) and lipogenic (glucose-6-phosphatase dehydrogenase) enzymes activities (mU/mg protein) in sea 4 bass fed the experimental diets during 4 weeks

\begin{tabular}{|c|c|c|c|c|}
\hline \multirow{2}{*}{$\begin{array}{l}\text { Temperature } \\
\text { Diets }\end{array}$} & \multicolumn{2}{|c|}{$25^{\circ} \mathrm{C}$} & \multicolumn{2}{|c|}{$18^{\circ} \mathrm{C}$} \\
\hline & WS & GLU & WS & GLU \\
\hline \multicolumn{5}{|l|}{ Glycolysis } \\
\hline Hexokinase & $0.53 \pm 0.47$ & $0.59 \pm 0.24$ & $0.38 \pm 0.33$ & $0.56 \pm 0.41$ \\
\hline Glucokinase & $2.6 \pm 1.3^{\mathrm{a}}$ & $13.1 \pm 7.9^{b}$ & $1.7 \pm 1.1^{\mathrm{a}}$ & $4.3 \pm 3.2^{b}$ \\
\hline Pyruvate Kinase & $66.7 \pm 9.1^{\mathrm{a}}$ & $110.3 \pm 26.2^{\mathrm{b}}$ & $68.9 \pm 10.8^{\mathrm{a}}$ & $90.0 \pm 13.3^{b}$ \\
\hline \multicolumn{5}{|l|}{ Gluconeogenesis } \\
\hline Fructose-1,6-bisphosphatase & $28.0 \pm 3.7$ & $24.6 \pm 3.7$ & $23.5 \pm 3.5^{a}$ & $20.1 \pm 2.7^{b}$ \\
\hline Glucose-6-phosphatase & $15.5 \pm 2.4$ & $16.3 \pm 3.4$ & $16.8 \pm 4.8$ & $16.1 \pm 2.9$ \\
\hline \multicolumn{5}{|l|}{ Lipogenesis } \\
\hline Glucose-6-phosphate dehydrogenase & $152.3 \pm 18.0^{\mathrm{a}}$ & $257.7 \pm 19.6^{\mathrm{b}}$ & $151.8 \pm 30.0^{\mathrm{a}}$ & $212.1 \pm 44.2^{\mathrm{b}}$ \\
\hline
\end{tabular}

Two-way ANOVA

Variation source ${ }^{1}$

Diet Temperature Interaction

Glycolysis

Hexokinase

ns ns ns

Glucokinase

Pyruvate Kinase

*** $\quad$ ** ns

*** ns ns

Gluconeogenesis

Fructose-1,6-bisphosphatase

Glucose-6-phosphatase

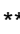

ns

$* * *$

ns

ns

ns

Lipogenesis

Glucose-6-phosphate dehydrogenase

Values are means \pm S.D. Significant differences within the diets are present by different letters (Tukey test, $P<0.05$ ).

${ }^{1}$ * $\mathrm{P}<0.05$; ** $\mathrm{P}<0.01$; ** $\mathrm{P}<0.001$; ns: non-significant. 
Table 5

Expression of hepatic HSP70 gene in sea bass reared at different temperatures

\begin{tabular}{|c|c|c|c|c|}
\hline Temperature & Diets & Type of regulation & & $\mathrm{p}$ value \\
\hline \multicolumn{5}{|c|}{ (control temperature: $25^{\circ} \mathrm{C}$ ) } \\
\hline \multirow[t]{2}{*}{$18^{\circ} \mathrm{C}$} & WS & no difference & & 0.708 \\
\hline & GLU & no difference & & 0.571 \\
\hline \multirow[t]{2}{*}{$18^{\circ} \mathrm{C}$ to $25^{\circ} \mathrm{C}$} & WS & no difference & & 0.535 \\
\hline & GLU & down-regulation & 1.2-fold & 0.021 \\
\hline \multicolumn{5}{|c|}{ (control temperature: $18^{\circ} \mathrm{C}$ ) } \\
\hline \multirow[t]{2}{*}{$18^{\circ} \mathrm{C}$ to $25^{\circ} \mathrm{C}$} & WS & no difference & & 0.776 \\
\hline & GLU & down-regulation & 1.3-fold & 0.003 \\
\hline \multicolumn{5}{|c|}{ EF1a gene expression - no variation } \\
\hline
\end{tabular}


(A)
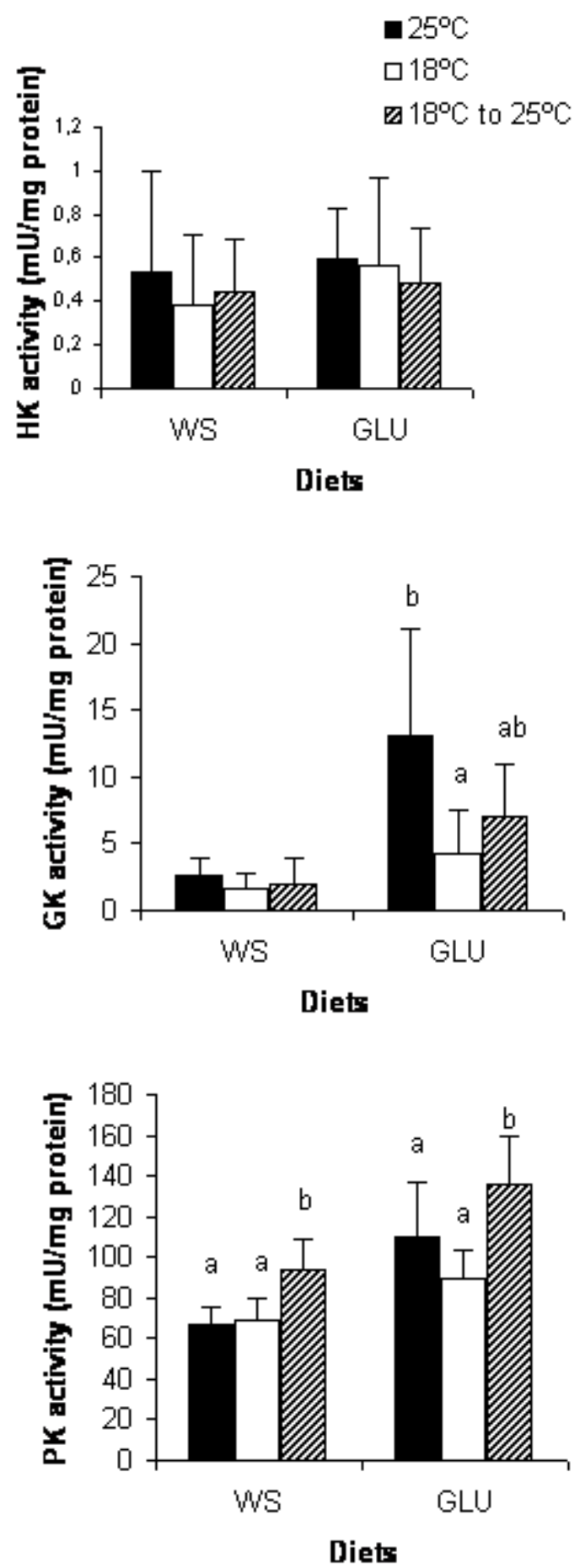

(B)
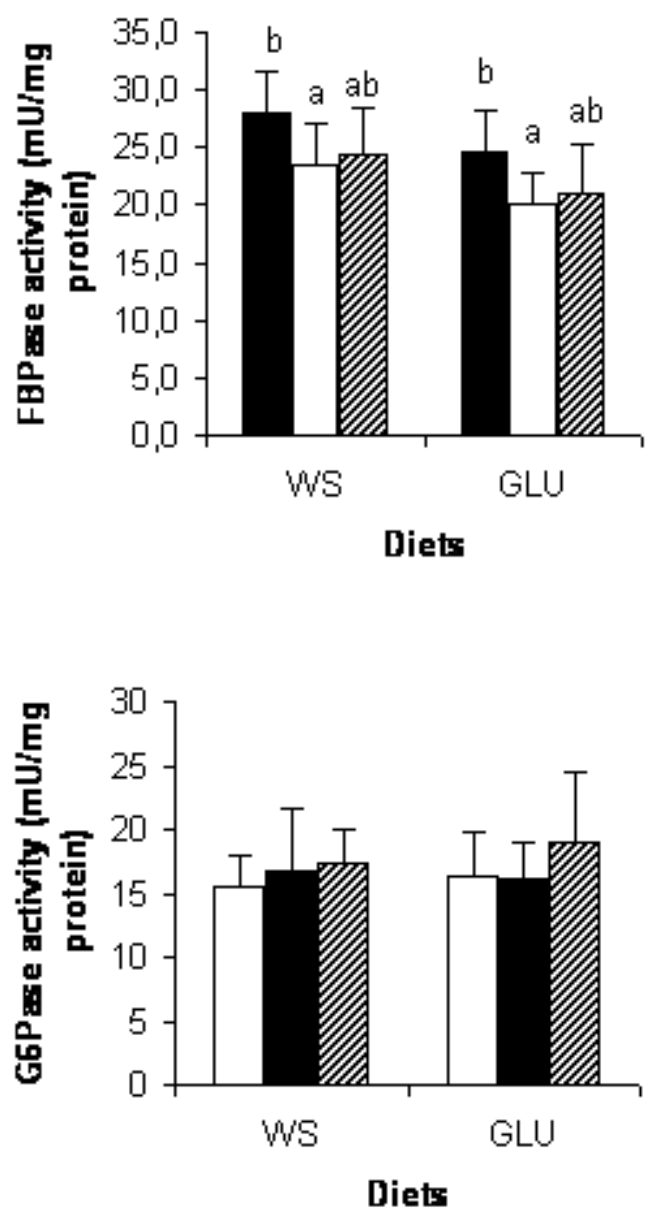

(C)

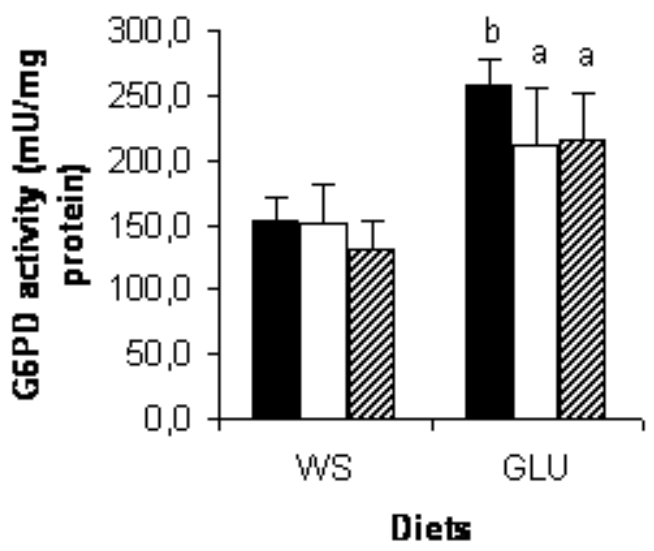

Fig. 1. Effect of water temperature on hepatic glycolytic (A), gluconeogenic (B) and lipogenic (C) enzyme activities in fish fed with waxy starch (WS) and glucose diet (GLU). At each diet, means are significantly different when they are represented by by different letters (Tukey test, $P<0.05$ ). 